\title{
Early life cycle of cephalopods in relation to the major oceanographic features of the southwest Atlantic Ocean
}

\author{
P. G. Rodhouse, C. Symon, E. M. C. Hatfield \\ British Antarctic Survey, Natural Environment Research Council, High Cross, Madingley Road, Cambridge CB3 0ET, United Kingdom
}

\begin{abstract}
Cephalopod paralarvae and juveniles were sampled with RMT8 and Bongo nets during 2 cruises of the MV 'Falklands Protector' in the southwest Atlantic Ocean in October/November 1990 and 1991 Each cruise had 2 phases, a northern phase over the Patagonian Shelf edge and adjacent waters, and a southern phase over the shelf around the Falkland Islands. Vertical temperature profiles were used to identify the major fronts and water masses. The subtropical water of the Brazil Current was characterized by the tropical/subtropical Abraliopsis pfefferi and Histioteuthis corona corona, the subtropical/subantarctic $H$. atlantica and the widespread Taningia danae, species of Brachioteuthis, Chiroteuthis and Galiteuthis, a single specimen of Illex argentinus and an ommastrephid rhynchoteuthion type B. The subantarctic surface water of the Falkland Current contained the richest assemblage of species and was characterised by the subtropical/subantarctic $H$. atlantica, the subantarctic Batoteuthis skolops, $H$. eltaninae, $H$. macrohista and the subantarctic/antarctic Gonatus antarcticus. With the exception of some small Gonatus antarcticus, the polar frontal zone water of the Falkland Current was relatively poor in species. The Falkland Islands Shelf yielded Loligo gahi, Gonatus antarcticus, Martialia hyadesi, Moroteuthis knipovitchi, Batoteuthis skolops, Semirossia patagonica and an Octopus sp. The data provide new information on the life cycles of Martialia hyadesi and Gonatus antarcticus and are consistent with the view that L. gahi reproduces in shallow water around the Falkland Islands with 1 major brood spawning in the late austral winter.
\end{abstract}

\section{INTRODUCTION}

The early stages in the life cycle of most cephalopod species have received little attention and are poorly understood. This is mainly due to difficulties with sampling, taxonomy and rearing young cephalopods (Vecchione 1987) and, despite the recent publication of a manual for paralarval and juvenile cephalopod identification (Sweeney et al. 1992) the young forms of many species, and some entire families, are still unknown. Consequently, there is much to be gained from the study of paralarval cephalopods, particularly for commercially and ecologically important species, since information on early life stages is required for the sustainable management of stocks.

In the southwest Atlantic Ocean major fisheries exist for 2 species of squid, Illex argentinus and Loligo gahi (Csirke 1987), and there are unexploited stocks of other species which are likely to be fished commer- cially in the future (Rodhouse 1990). Although there has been recent progress in understanding the early life cycle of $I$, argentinus (Brunetti 1990, Brunetti \& Ivanovic 1992) there is considerably less information on the paralarval biology of most of the other important species of cephalopods in the southwest Atlantic Ocean. A number of these species are an important food resource for vertebrate predators (Clarke 1980, Rodhouse et al. 1987, 1990, 1992, Thompson 1989).

This paper examines the distribution of paralarval and juvenile cephalopods in the southwest Atlantic Ocean in relation to the major oceanographic features of the region. The data were collected during 2 research cruises on the Falkland Islands Government Fisheries Department vessel, MV 'Falklands Protector', in the austral spring of 1990 and 1991. To minimise the limitations of currently available sampling gear, 2 net types were employed: an RMT8 and a Bongo pair. Both nets were deployed at each station in 1990, with Bongo 
nets deployed at offshore and RMT8 nets at inshore stations in 1991. Because of limitations imposed by damage to some of the specimens, a lack of intermediate-size specimens linking juvenile to adult forms and an incomplete knowledge of the teuthofauna of the region, the taxonomy of the cephalopod material from this survey is necessarily incomplete. However, the identification of the major commercial species and several of the more ecologically important muscular cephalopods is sufficient for progress to be made in understanding their early life cycles.

\section{STUDY AREA}

Given the role of ocean currents in the transport of cephalopod paralarvae, and the dominant influence of the oceanographic regime on the ecology of the southwest Atlantic Ocean, any analysis of cephalopod paralarval distribution requires an investigation of the prevailing oceanographic conditions.

The major oceanographic features of the southwest Atlantic Ocean are the Brazil Current, the Falkland Current and their confluence region (Fig. 1). These strongly flowing western boundary currents are reviewed by Legeckis \& Gordon (1982), Gordon \& Greengrove (1986), Garzoli \& Biabchi (1987), Olson et al. (1988), Peterson \& Whitworth (1989) and Stramma \& Peterson (1990). Both currents are highly stratified water bodies and occur immediately offshore of the South American continental shelf. The Falkland Current is approximately $100 \mathrm{~km}$ wide and originates as a branch of the Antarctic Circumpolar Current, carrying subantarctic and polar frontal zone water northwards along the shelf break. The western edge of the Falkland Current is approximately coincident with the $200 \mathrm{~m}$ isobath while the northern edge is bounded by the warmer waters of the Brazil Current. The Brazil Current (the western boundary of the South Atlantic Subtropical Gyre) begins at around $8^{\circ} \mathrm{S}$ and carries subtropical water southwards along the shelf edge until it meets the Falkland Current in a major confluence referred to as the Subtropical Front. Following their confluence both currents move offshore and, with the Brazil Current dominating, move in a southeasterly direction to at least $40^{\circ} \mathrm{S}$ at which point the currents separate and the Brazil Current turns northwards to form a quasi-stationary meander of South Atlantic Central Water. The southern limit of the Brazil Current fluctuates between 38 and $46^{\circ} \mathrm{S}$ due to the intermittent shedding of large warm core eddies. Eddies and other thermal features are often observed within the band of intermediate water separating the 2 currents. Current speeds are high and the following were observed using surface drifters (Gordon \& Greengrove 1986):

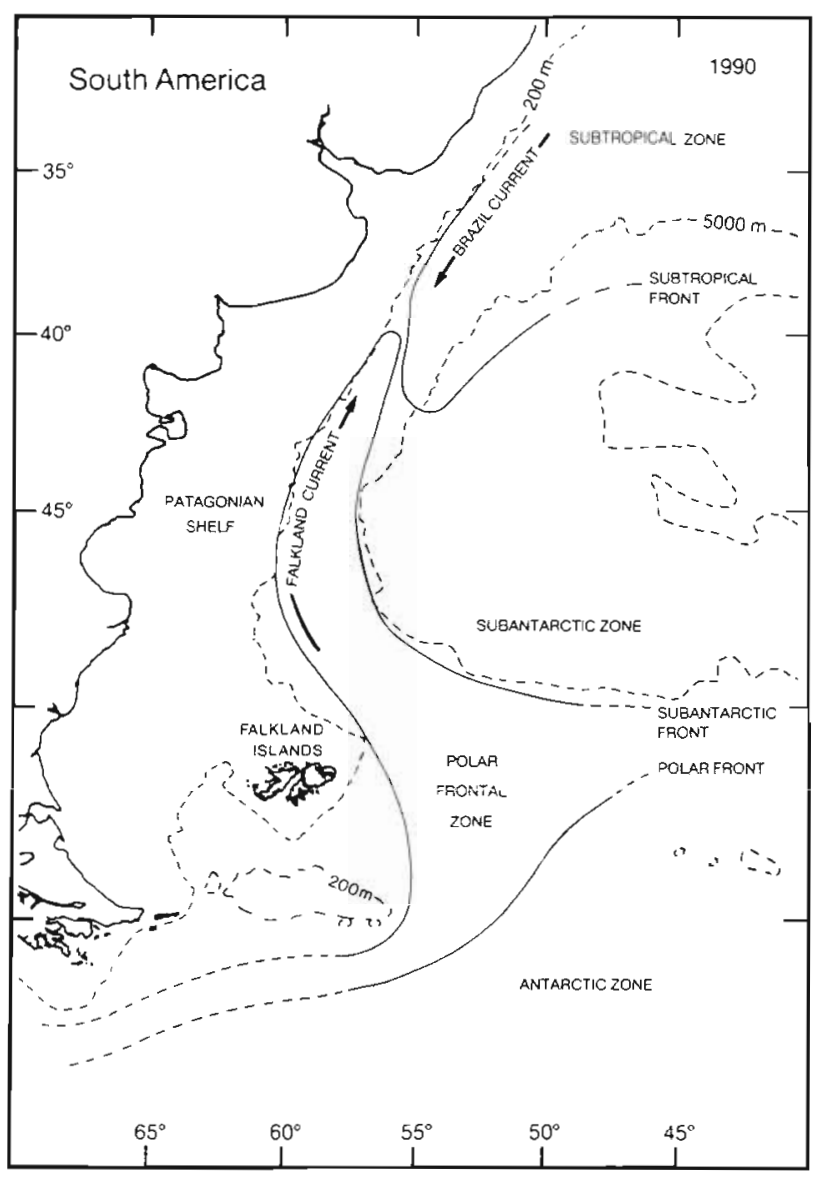

Fig. 1. Major oceanographic features of the southwest Atlantic Ocean

Falkland Current ( 35 and $40 \mathrm{~cm} \mathrm{~s}^{-1}$ ); Falkland Current return (55 and $65 \mathrm{~cm} \mathrm{~s}^{-1}$ ); confluence region (85 and $\left.98 \mathrm{~cm} \mathrm{~s}^{-1}\right)$; Brazil Current $\left(68 \mathrm{~cm} \mathrm{~s}^{-1}\right)$; and the Brazil Current return $\left(27,42\right.$ and $\left.64 \mathrm{~cm} \mathrm{~s}^{-1}\right)$.

This study assumes the widely used nomenclature for the fronts and zones adopted by Peterson \& Whitworth (1989) such that from north to south the following are observed: Subtropical Zone (STZ), Subtropical Front (STF), Subantarctic Zone (SAZ), Subantarctic Front (SAF), Polar Frontal Zone (PFZ), Polar Front (PF) and Antarctic Zone (AAZ) (Fig. 1).

\section{MATERIALS AND METHODS}

Sampling methods. The study area was surveyed 7 October to 9 November 1990 and 28 October to 30 November 1991. Each cruise contained a northern and a southern phase (Fig. 2). In both cruises the northern phase consisted of a series of latitudinal transects across the Patagonian slope limited to the west by the South American 200 mile zone; in 1990 the transects 

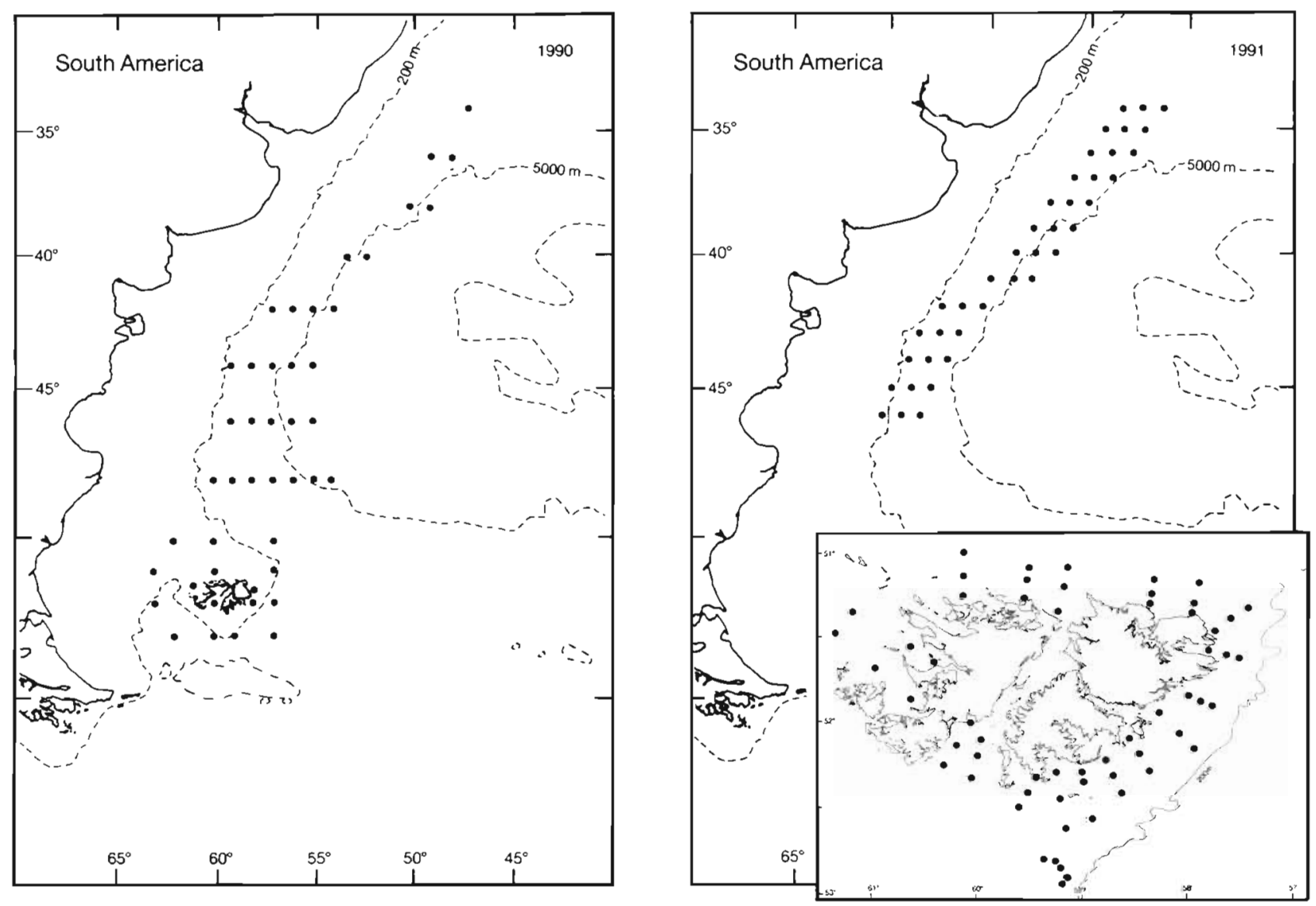

Fig. 2. Survey sites: 1990 and 1991

occurred at $2^{\circ}$ latitude intervals and in 1991 at $1^{\circ}$ latitude intervals. The southern phase was focused on the Falkland Island shelf and consisted of a series of latitudinal transects in 1990 with transects radiating from the islands in 1991.

Cephalopods were sampled with a single RMT8 net (Clarke 1969) and a $600 \mathrm{~mm}$ diameter Bongo pair. Hauls were carried out at a nominal 2 knots in 1990 and 2.5 knots in 1991 with net depths monitored by an IOS acoustic monitor (RMT8) and a Benthos timedepth recorder (Bongo).

In 1990, Bongo nets with a $335 \mu \mathrm{m}$ mesh were deployed for 30 min surface hauls in both the northern and southern phases, while the RMT8 was deployed for $90 \mathrm{~min}$ downward oblique hauls to $300 \mathrm{~m}$ in the northern phase and for 60 min downward oblique hauls to $200 \mathrm{~m}$ (or the bottom) in the southern phase. In 1991, Bongo nets with a $500 \mu \mathrm{m}$ mesh were deployed for $30 \mathrm{~min}$ downward oblique hauls to $50 \mathrm{~m}$ during the northern phase with the RMT8 deployed as follows during the southern phase: $30 \mathrm{~min}$ downward oblique to near the bottom, 30 min immediately above the bottom and 30 min upwards oblique to the surface.
Vertical temperature profiles were obtained for the upper $750 \mathrm{~m}$ of water using $\mathrm{T} 7$ expendable bathythermographs (XBT's). An XBT was deployed at each sample site in the northern phase of the 1990 and 1991 surveys and on 2 transects in the vicinity of the Falkland Islands during the 1990 survey.

Treatment of samples. The samples were handsorted at sea and most cephalopods picked out and fixed in $5 \%$ buffered formalin. The remaining cephalopods were removed by intensive sorting ashore and the settled volume of the remaining zooplankton was determined. All cephalopods were identified to the lowest possible taxon and the dorsal mantle length (ML) was determined to the nearest $0.1 \mathrm{~mm}$ (these are the ML's reported in Table 1). The non-ommastrephid cephalopod samples were then preserved in Steedman's solution (Steedman 1976).

In order to examine the ommastrephid rhynchoteuthion paralarvae with a Leica \$360 scanning electron microscope (SEM) the formalin-fixed specimens were (1) transferred through an ascending series of acetone concentrations in water $(25,50$ and $75 \%)$, (2) placed in $100 \%$ acetone, (3) put through 2 changes 
of $100 \%$ dry acetone for $30 \mathrm{~min}$ each, (4) criticalpoint dried in liquid $\mathrm{CO}_{2}$ and (5) mounted on SEM stubs with double-sided tape or colloidal silver and sputter-coated with gold. The ML, proboscis length (PL) and the diameter of proboscis suckers
(SDp) were determined for each paralarvae. ML shrank by $24.8 \pm 9.0 \%$ during preparation for the SEM. In order to determine the proboscis index (PI) (see Table 2) proportional shrinkage of the mantle and proboscis was assumed.

Table 1. Cephalopod species taken by RMT8 and Bongo nets in the southwest Atlantic Ocean, 1990 and 1991. nm: not measurable

\begin{tabular}{|c|c|c|c|c|}
\hline $\begin{array}{l}\text { Family } \\
\text { Species }\end{array}$ & $\begin{array}{l}\text { Sample } \\
\text { size }\end{array}$ & $\begin{array}{c}\mathrm{ML} \\
(\mathrm{mm})\end{array}$ & Net type & $\begin{array}{l}\text { ' First published record of paralarvae and small } \\
\text { juveniles. Distinct lappet on dorsal midline at anterior } \\
\text { margin of mantle (Brakonierki 1984) apparent in all }\end{array}$ \\
\hline \multicolumn{4}{|l|}{ Sepiolidae } & sizes (see Fig. 3) \\
\hline $\begin{array}{l}\text { Sepiolidae } \\
\text { Semirossia patagonica }\end{array}$ & 132 & $5-27$ & RMT8 & $\begin{array}{l}{ }^{b} \text { Club armature not developed in small specimens, } \\
\text { however tetraserial arm armature confirms specimens }\end{array}$ \\
\hline \multicolumn{4}{|l|}{ Loliginidae } & $\begin{array}{l}\text { as gonatids. Club armature evident in larger speci- } \\
\text { mens, although characteristic hook pattern (Kubodera }\end{array}$ \\
\hline Loligo gahia & 147 & $8-44$ & RMT8 & $\begin{array}{l}\text { \& Okutani 1986) not fully developed. Only known } \\
\text { gonatid in southwest Atlantic Ocean is Gonatus }\end{array}$ \\
\hline \multicolumn{4}{|l|}{ Enoploteuthidae } & antarcticus (Kubodera \& Okutani 1986) thus all \\
\hline Abraliopsis pfefferi & 4 & $21-32$ & RMT8 & $\begin{array}{l}\text { material identified as young } G \text {. antarcticus } \\
\text { 'Identified as Moroteuthis knipovitchi because skin }\end{array}$ \\
\hline \multicolumn{4}{|l|}{ Octopoteuthidae } & $\begin{array}{l}\text { lacks papillations or wrinkling of } M \text {. ingens (Sweeney et } \\
\text { al. 1992) which also occurs in southwest Atlantic Ocean }\end{array}$ \\
\hline Taningia danae & 1 & 13 & Kiva 18 & $\begin{array}{l}\text { d Possesses needle-like tail of young form described by } \\
\text { Young \& Roper (1968) }\end{array}$ \\
\hline $\begin{array}{l}\text { Gonatidae } \\
\text { Gonatus antarcticus }\end{array}$ & 434 & $2-32$ & RMT8/Bongo & $\begin{array}{l}\text { 'Family in need of revision (Roper 1983, Sweeney et } \\
\text { al. 1992) thus no species name assigned. Mantles of }\end{array}$ \\
\hline \multicolumn{4}{|l|}{ Onychoteuthidae } & $\begin{array}{l}\text { Juvenile/subadults slender with smooth skin. No } \\
\text { photophores on eyes }\end{array}$ \\
\hline Moroteuthis knipovitchic & 3 & $23-32$ & RMT8 & $\begin{array}{l}\text { Identification confirmed by Prof. N. Voss. First record } \\
\text { of Histioteuthis corona corona in southwest Atlantic } \\
\text { Ocean (see Voss 1969) }\end{array}$ \\
\hline Batoteuthis skolops & 2 & $36-49$ & RMT8 & $\begin{array}{l}\text { 9 Small juvenile, fits description given by Uozomi et } \\
\text { al. (1991). Also linked to adult material (Rodhouse \& } \\
\text { Yeatman 1990) }\end{array}$ \\
\hline Brachioteuthis sp. or spp..$^{\mathrm{e}}$ & 5 & $8-107$ & RMT8/Bongo & $\begin{array}{l}\text { ' Type C rhynchoteuthion (Roper \& Lu 1979) identified } \\
\text { as IIlex argentinus (Brunetti 1990) by PI and SDI (see } \\
\text { Table 2) }\end{array}$ \\
\hline Histioteuthidae & 5 & $28-58$ & & $\begin{array}{l}\text { Table 2) } \\
\text { Identified as type B rhynchoteuthions by PI and SDI }\end{array}$ \\
\hline & 1 & $\begin{array}{c}28-58 \\
10\end{array}$ & $\begin{array}{l}\text { RMT8 } \\
\text { RMT8 }\end{array}$ & $\begin{array}{l}\text { Identified as type } B \text { rhynchoteuthions by PI and SDI } \\
\text { (see Table 2). } 16-21 \text { knobs on inner whorl of outer }\end{array}$ \\
\hline $\begin{array}{l}\text { Histioteuthis corona coronat } \\
\text { Histioteuthis eltaninae }\end{array}$ & 4 & $9-74$ & $\begin{array}{l}\text { RM18 } \\
\text { RMT8/Bongo }\end{array}$ & chitinous sucker ring of large lateral suckers, with \\
\hline & 2 & $38-44$ & $\begin{array}{l}\text { RMi8/Bongo } \\
\text { RMT8 }\end{array}$ & 11-13 knobs on medial suckers. Chromatophores \\
\hline $\begin{array}{l}\text { Histioteuthis macrohista } \\
\text { Histioteuthis sp. }\end{array}$ & 1 & $\mathrm{~nm}$ & RMT8 & $\begin{array}{l}\text { poorly preserved and no photophores apparent on } \\
\text { ventral surface of eyes (see Fig. } 4 \text { ) }\end{array}$ \\
\hline \multicolumn{4}{|l|}{ Ommastrephidae } & $\begin{array}{l}\text { Small juveniles identified by characteristic omma- } \\
\text { strephid funnel connectives (Roper el al. 1969). Dacty- }\end{array}$ \\
\hline Martialia hyadesi 9 & 7 & $21-33$ & RMT8 & lus suckers in 2 rows for 2 specimens, dactylus suckers \\
\hline \multicolumn{4}{|l|}{ Illex argentinus } & lost for third specimen. Funnel groove did not possess \\
\hline (Rhynchoteuthion type $C)^{h}$ & 1 & 4 & Bongo & foveola or side pockets. No lower taxa assigned due to \\
\hline Rhynchoteuthion type $B^{\prime}$ & 7 & $3-4$ & Bongo & uncertainty over size at which characters appear and \\
\hline $\begin{array}{l}\text { Unidentified } \\
\text { ommastrephids }\end{array}$ & 5 & $9-14$ & RMT8/Bongo & $\begin{array}{l}\text { no adult material available to link specimens } \\
\text { No lower taxa assigned as family under revision } \\
\text { (Roper 1983) }\end{array}$ \\
\hline \multicolumn{4}{|l|}{ Chiroteuthidae } & I Unidentifiable due to damage or lack of suitable char- \\
\hline Chiroteuthis sp. & 2 & $42-48$ & RMT8 & $\begin{array}{l}\text { acters (given the current state of knowledge). Eleven } \\
\text { damaged specimens with a row of } 3 \text { blue photophores } \\
\text { on ventral surface of eye }\end{array}$ \\
\hline \multicolumn{4}{|l|}{ Cranchiidae } & ${ }^{\mathrm{m}}$ Arm suckers in 2 rows with no enlarged suckers. Skin \\
\hline Galiteuthis sp. & 8 & $50-106$ & RMT8 & smooth. Body muscular and web extended to $20-25 \%$ \\
\hline Teuthoweniasp. & 1 & 43 & RMT8 & of arm length. Eye diameter approximately $30 \% \mathrm{ML}$. \\
\hline Unidentified cranchiids & 22 & $4-25$ & RMT8 & $\begin{array}{l}\text { Small brown chromatophores more densely concen- } \\
\text { trated over head than mantle and denser on dorsal }\end{array}$ \\
\hline Unidentified teuthoids' & 168 & $3-20$ & RMT8/Bongo & $\begin{array}{l}\text { rather than ventral mantle surface. Single row of } \\
\text { chromatophores along the centre of each arm lap- }\end{array}$ \\
\hline \multicolumn{4}{|l|}{ Octopodidae } & proximately same size as on head and mantle and \\
\hline Octopus sp. ${ }^{m}$ & 1439 & $3-13$ & RMT8 & $\begin{array}{l}\text { along each side of each arm (see Fig. S). No lower taxa } \\
\text { assigned. All undamaged specimens a ppear to belong }\end{array}$ \\
\hline Haliphron atlanticus & 1 & 14 & RMT8 & to 1 species \\
\hline
\end{tabular}




\section{RESULTS}

\section{Cephalopod taxonomy}

Cephalopods were obtained from the orders Sepioidea ( 1 family), Teuthoidea ( 1 myopsid and 10 oegopsid families) and Octopoda ( 2 families). Table 1 (and associated Figs. 3 to 5) reviews this information and provides the species names (where possible), the numbers of specimens, the range in ML (all formalin-fixed specimens) and the net types with which the samples were obtained. Several taxonomic problems are highlighted by the collection. Of the families represented, 7 (Enoploteuthidae, Gonatidae, Brachioteuthidae, Ommastrephidae, Chiroteuthidae, Cranchiidae, Octopodidae) are presently under revision (Roper 1983) and given the current state of knowledge no attempt was made to name specimens from the Brachioteuthidae, Chiroteuthidae or Cranchiidae. The young Octopus specimens are currently unidentifiable, but appear to belong to 1 species (Table 1, Fig. 5).

Given the commercial and ecological importance of the Ommastrephidae in the southwest Atlantic Ocean there is a need for more information on ommastrephid paralarvae, especially the rhynchoteuthion stage. On the basis of Brunetti's (1990) description, the single type $\mathrm{C}$ rhynchoteuthion in this collection is identified as Illex argentinus (Tables $1 \& 2$, Fig. 4). The identification of the type B specimens however, is problematical. It has been suggested that type B rhynchoteuthions from the north Atlantic Ocean are Ornithoteuthis antillarum (Roper \& Lu 1979) and although this species extends to Uruguay in the southwest Atlantic Ocean (Nesis 1987), from material presently available it cannot be linked through size-series with the type B rhynchoteuthions caught in this study. Specimens from a wide size range are required to relate rhynchoteuthions to the adult with confidence (cf. Roper \& Lu 1979, Harman \& Young 1985, Young \& Hirota 1990).

Net performance. The larger of the 2 nets, the RMT8, generally caught larger cephalopods than the $335 \mu \mathrm{m}$ or $500 \mu \mathrm{m}$ mesh Bongo, while the latter was more effective at catching small paralarvae. In 1990 , 157 Gonatus antarcticus (maximum ML $=12 \mathrm{~mm}$ ) were caught with the $335 \mu \mathrm{m}$ Bongo. This muscular species is probably among the most effective at net avoidance so it appears that the Bongo effectively samples small muscular paralarvae when they are present. The RMT8 was most successful over the Falkland Shelf, especially when fished close to the seabed, catching a relatively large number of Loligo gahi, G. antarcticus, Semirossia patagonica and Octopus sp. and a smaller number of Martialia hyadesi. In the case of $G$. antarcticus, the larger specimens obtained with the RMT8 extended the size range caught by the Bongo net.

\section{Oceanographic conditions}

Both XBT surveys were completed in a north to south direction, taking $15 \mathrm{~d}$ in 1990 and $10 \mathrm{~d}$ in 1991 . Since satellite imagery and inverted echo sounders have shown the Brazil Current extension to oscillate around its mean position at periods of 1 to 2 mo (Legeckis \& Gordon 1982, Garzoli \& Biabchi 1987) the dynamic nature of the region should not be ignored. However, because the majority of the variability is concentrated at the STF and because the STF was surveyed in less than a week during both surveys, for the purposes of this study the surveys are assumed to be synoptic.

Although frontal positions are generally determined using both temperature and salinity, in this instance temperature alone is sufficient (the water masses in this region have strong thermal signals and surface temperatures decreased from $>20^{\circ} \mathrm{C}$ in the north to approximately $5^{\circ} \mathrm{C}$ in the south). With reference to the review by Peterson \& Whitworth (1989) the XBT temperature-depth profiles were used to locate the various fronts and zones as follows:
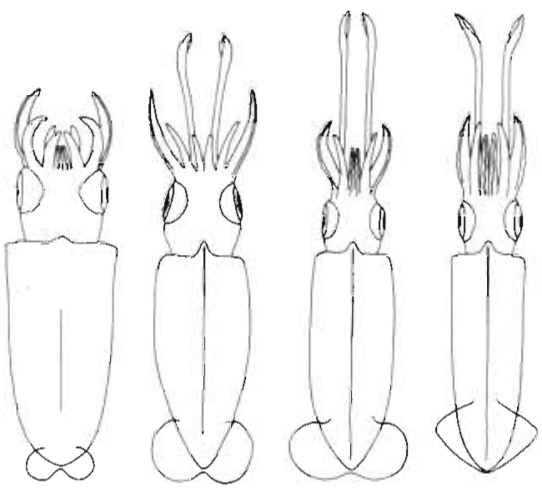

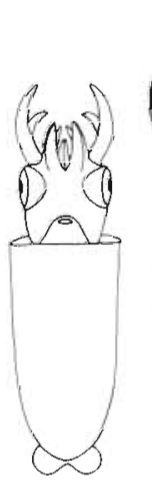

17

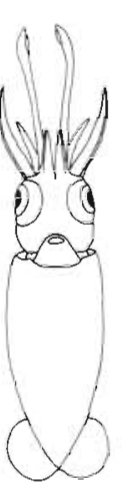

13
22

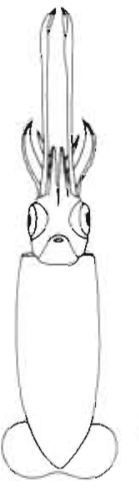

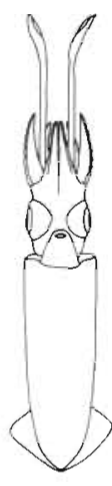

$41 \mathrm{~mm} \mathrm{ML}$
Fig. 3. Loligo gahi. Dorsal views (upper row) and ventral views (lower row) (with the scales adjusted to make the given ML's appear equal) 


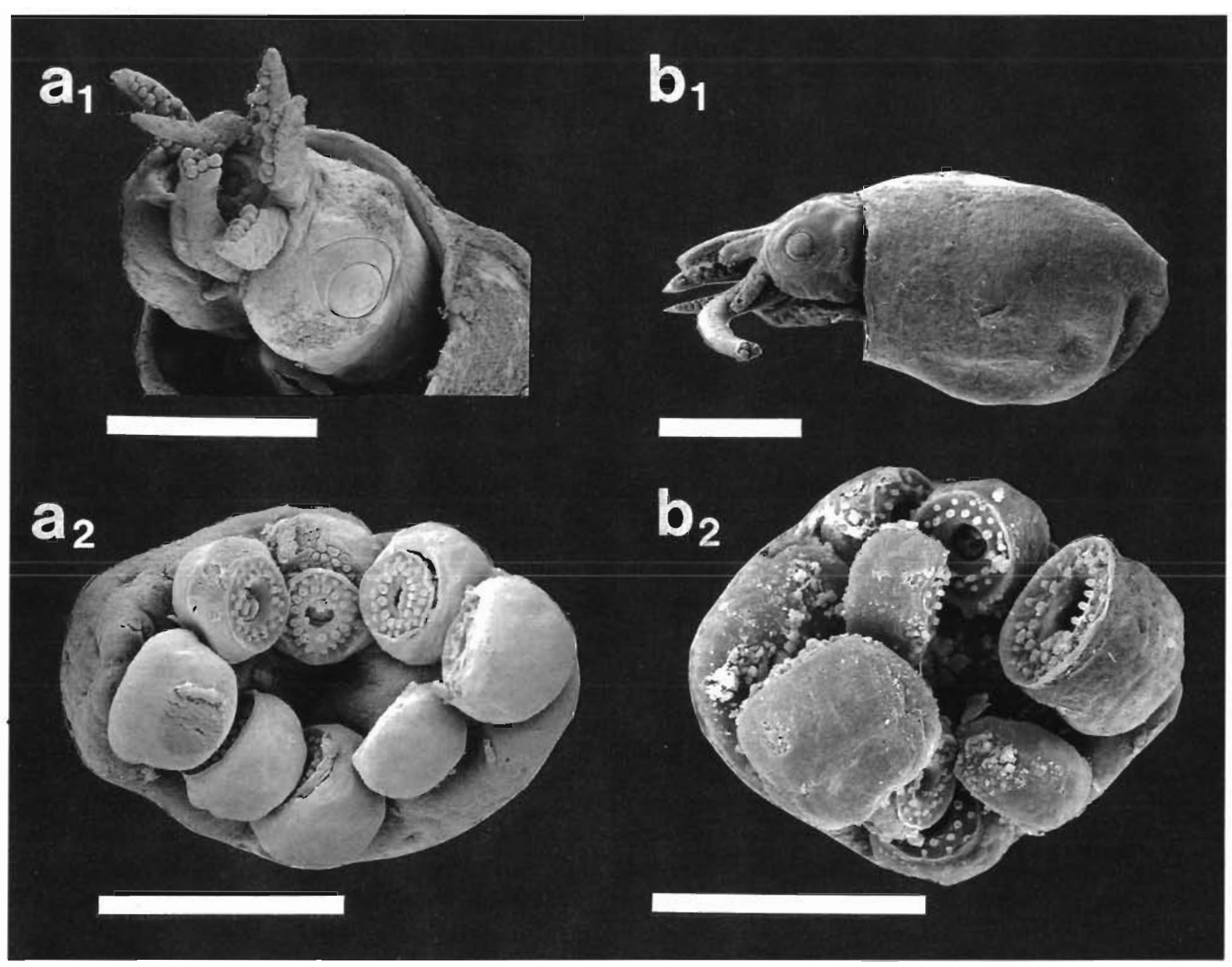

Fig. 4. Illex spp. Scanning electron micrographs of ommastrephid rhynchoteuthion stages: $\left(\mathrm{a}_{1}\right)$ I. argentinus head showing short proboscis; $\left(a_{2}\right)$ I. argentinus proboscis tip showing equal sized lateral and medial suckers; $\left(b_{1}\right)$ rhynchoteuthion type $B$ lateral view showing long proboscis; $\left(b_{2}\right)$ rhynchoteuthin type $B$ proboscis tip showing enlarged lateral suckers. Scale bars: $\left(a_{1}\right)$ and $\left(b_{1}\right)=1 \mathrm{~mm}_{i}\left(\mathrm{a}_{2}\right)$ and $\left(\mathrm{b}_{2}\right)=100 \mu \mathrm{m}$

STF: $\quad$ the $8^{\circ} \mathrm{C}$ isotherm $>500 \mathrm{~m}$ deep (Roden 1986).

SAZ: $\quad$ the $4^{\circ} \mathrm{C}$ isotherm $>500 \mathrm{~m}$ deep.

SAF: $\quad$ the northern extent of the $4{ }^{\circ} \mathrm{C}$ isotherm at $200 \mathrm{~m}$.

PFZ: $\quad$ the $4{ }^{\circ} \mathrm{C}$ isotherm $<200 \mathrm{~m}$ deep and deepening rapidly towards the $\mathrm{SAF}$

PF: the northern extent of the $2{ }^{\circ} \mathrm{C}$ isotherm near $200 \mathrm{~m}$

AAZ: a temperature minimum of $<2{ }^{\circ} \mathrm{C}$ which is $<200 \mathrm{~m}$ deep.

The major oceanographic features of the 1990 and 1991 surveys are shown in Fig. 6. In both surveys the following features were evident; a STZ, the STF, a SAZ, the SAF and a PFZ. Flowing northward within the Falkland Current are 2 major types of water derived from the
Antarctic Circumpolar Current; PFZ water and SAZ water. The extent to which the PFZ component penetrated northwards was greater in 1991 reaching $40^{\circ} \mathrm{S}$, with the northern limit of the SAF further south at around $43^{\circ} \mathrm{S}$ in 1990 . It was difficult to compare the spatial dimensions of the PFZ's due to variation in the areas surveyed. In 1990 a greater area was sampled to the south and east, i.e. the area dominated by the Falkland Current, while the region to the north was sampled more extensively in 1991 giving more detail of the Brazil Current and associated features. Fig. 6 shows evidence of recent eddy generation in 1991, with a large warm core eddy (WCE) centred in the vicinity of 37 to $38^{\circ} \mathrm{S}$ and a smaller WCE at $40^{\circ} \mathrm{S}$. There was a small cold core eddy at $41^{\circ} \mathrm{S}$ in 1991 . The presence of WCE's probably accounts for the more northerly position of the STF in 1991 (35 to $\left.36^{\circ} \mathrm{S}\right)$, relative to $1990\left(37\right.$ to $\left.38^{\circ} \mathrm{S}\right)$ 

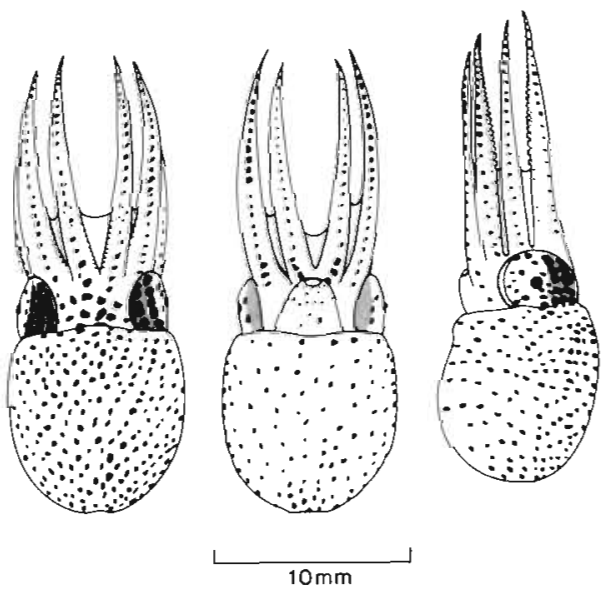

Fig. 5. Octopus sp. Dorsal, ventral and lateral view of specimen $(\mathrm{ML}=9 \mathrm{~mm})$ from the shelf around the Falkland Islands

The Falkland Island shelf waters were considerably less variable with surface temperatures ranging from 5 to $7^{\circ} \mathrm{C}$ in 1990 (the only year in which XBT's were deployed). At the inner stations the waters were completely mixed with some surface stratification at the deeper sites (i.e. waters of 100 to $200 \mathrm{~m}$ depth).

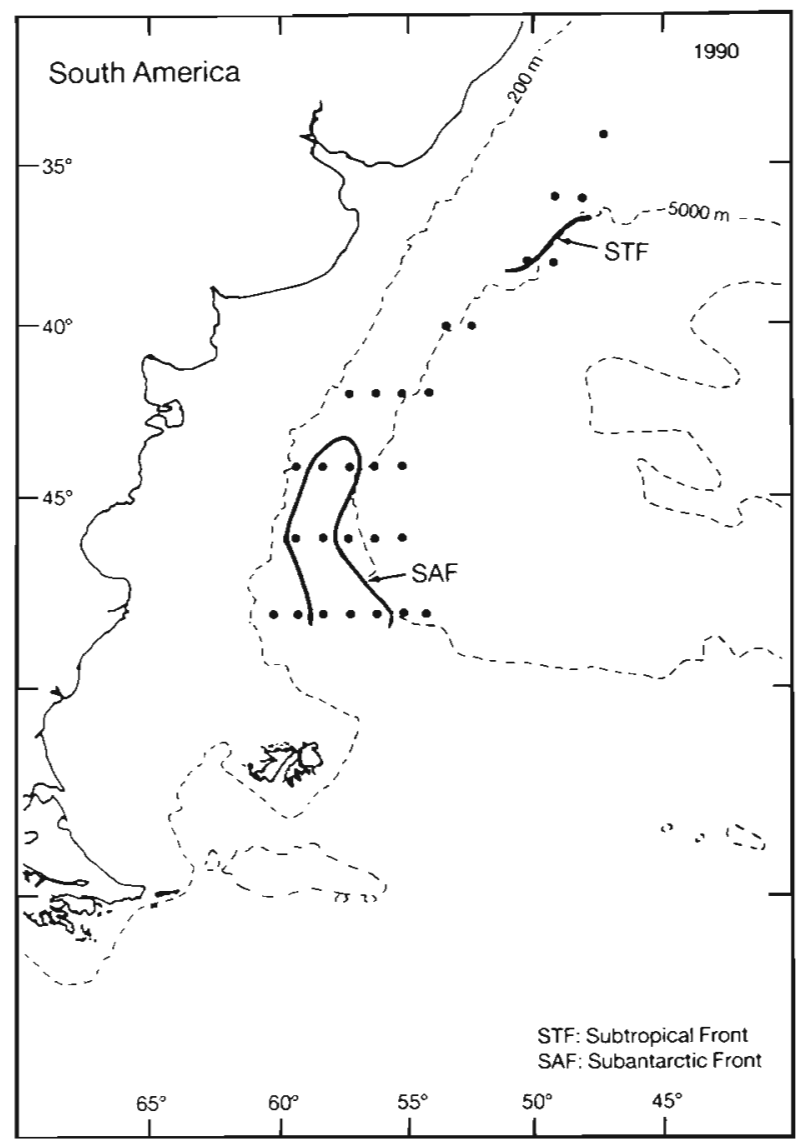

Table 2. Mantie length and indices of rhynchoteuthion larvae. ML: mantle length in $\mathrm{mm}$; PI: proboscis index (ratio of proboscis length in $\mathrm{mm}$ to $\mathrm{ML}$ ); SDI: mean sucker diameter index (ratio of the diameter of the 6 medial suckers to the diameter of the 2 lateral suckers on the tip of the proboscis); nm: not measurable

\begin{tabular}{|cccc|}
\hline $\begin{array}{c}\text { Rhynchoteuthion } \\
\text { type }\end{array}$ & ML & PI & SDI \\
\hline B & 2.8 & 0.65 & 0.63 \\
B & $n m$ & - & 0.73 \\
B & 2.5 & 0.44 & $n m$ \\
B & 3.1 & 0.41 & 0.67 \\
B & 3.9 & 0.51 & 0.64 \\
B & 3.8 & 0.56 & 0.64 \\
C & 3.5 & 0.27 & 0.98 \\
\hline
\end{tabular}

\section{Zooplankton settled volume}

Zooplankton settled volumes from each $30 \mathrm{~min}$ Bongo haul are shown in Fig. 7. Greater zooplankton volumes were obtained in 1991 when the top $50 \mathrm{~m}$ of the water column were sampled than in 1990 when only surface waters were sampled. In 1990 greatest zooplankton volumes were associated with stations

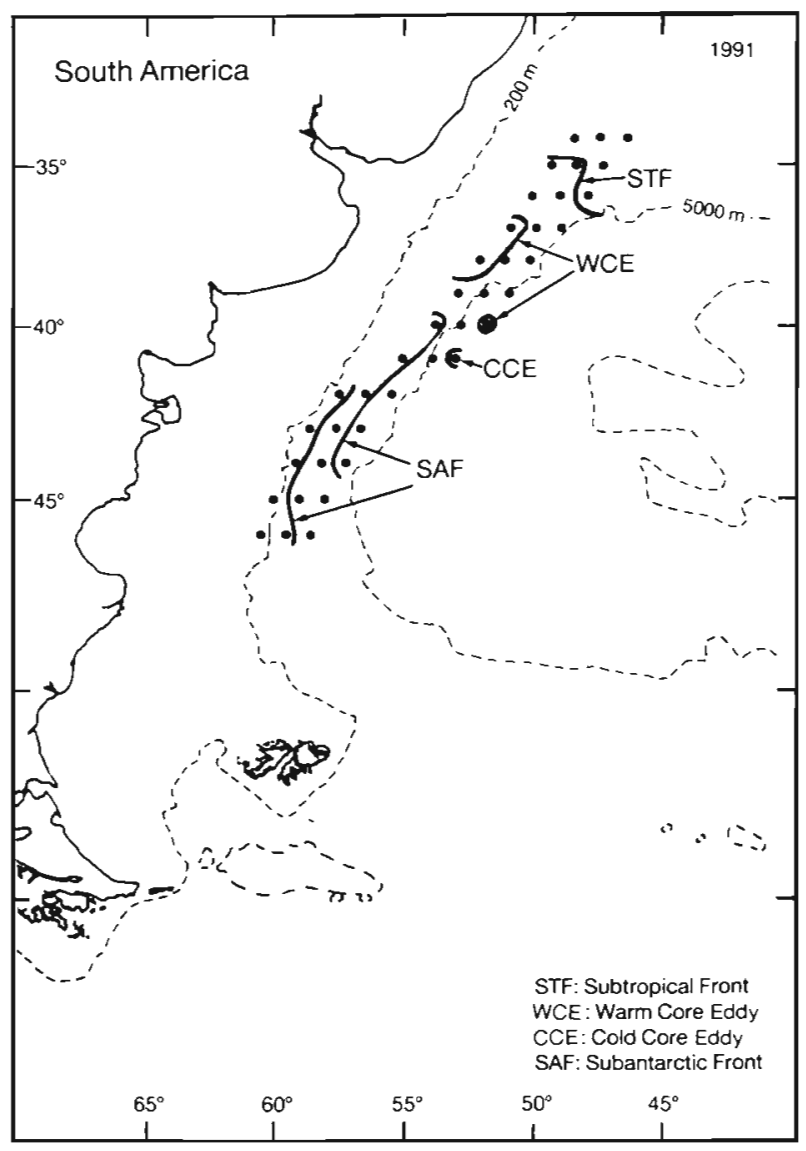

Fig. 6. Major oceanographic features: 1990 and 1991 
over the $5000 \mathrm{~m}$ isobath; corresponding to the SAF in the south and the STF in the north. There is a less obvious association between zooplankton volume and bathymetric/oceanographic features in 1991, although the greatest volumes are again observed at the $5000 \mathrm{~m}$ stations. With one exception, the smallest zooplankton volumes occurred over the shelf around the Falkland Islands.

\section{Zoogeography}

Distributions of cephalopod species in relation to the STZ, the SAZ and the PFZ are given in Tables $3 \& 4$ (only whole specimens of unidentified teuthoids are reported). In 1990, samples were obtained from the top $300 \mathrm{~m}$ using an RMT8 and from the surface using a Bongo net. In 1991 the RMT8 was not used in the northern phase and a Bongo pair was used to sample the top $50 \mathrm{~m}$ only. Over the depth of the hauls, the waters sampled were South Atlantic Central Water in the STZ, Subantarctic Surface Water in the SAZ and a mixture of Subantarctic and Antarctic Surface Water in the PFZ. Although sample regions, net combinations and sample depth varied for the 2 surveys, the association between cephalopod type and water type is marked.

In 1990, the Brazil Current was characterised by the tropical/subtropical Abraliopsis pfefferi and Histioteuthis corona corona (both caught well into the STZ away from the STF), the subtropical/subantarctic H. atlantica and the widespread Taningia danae, and Brachioteuthis, Chiroteuthis and Galiteuthis spp. The single specimen of $H$. corona corona was caught at $35^{\circ} \mathrm{S} 48^{\circ} \mathrm{W}$ and is the first record for the southwest Atlantic Ocean. In 1991 the species caught were ommastrephid rhynchoteuthion paralarvae types B and $C$ (caught well into the STZ away from the STF) and some unidentified teuthoids (caught mainly in the large warm core eddy).

The SAZ contained the richest assemblage of species. Apart from a single specimen of the tropical/ subtropical Abraliopsis pfefferi (caught close to the STF) and a single specimen of the widespread Haliphron atlanticus, the SAZ was characterised by the subtropical/subantarctic Histioteuthis atlantica (caught
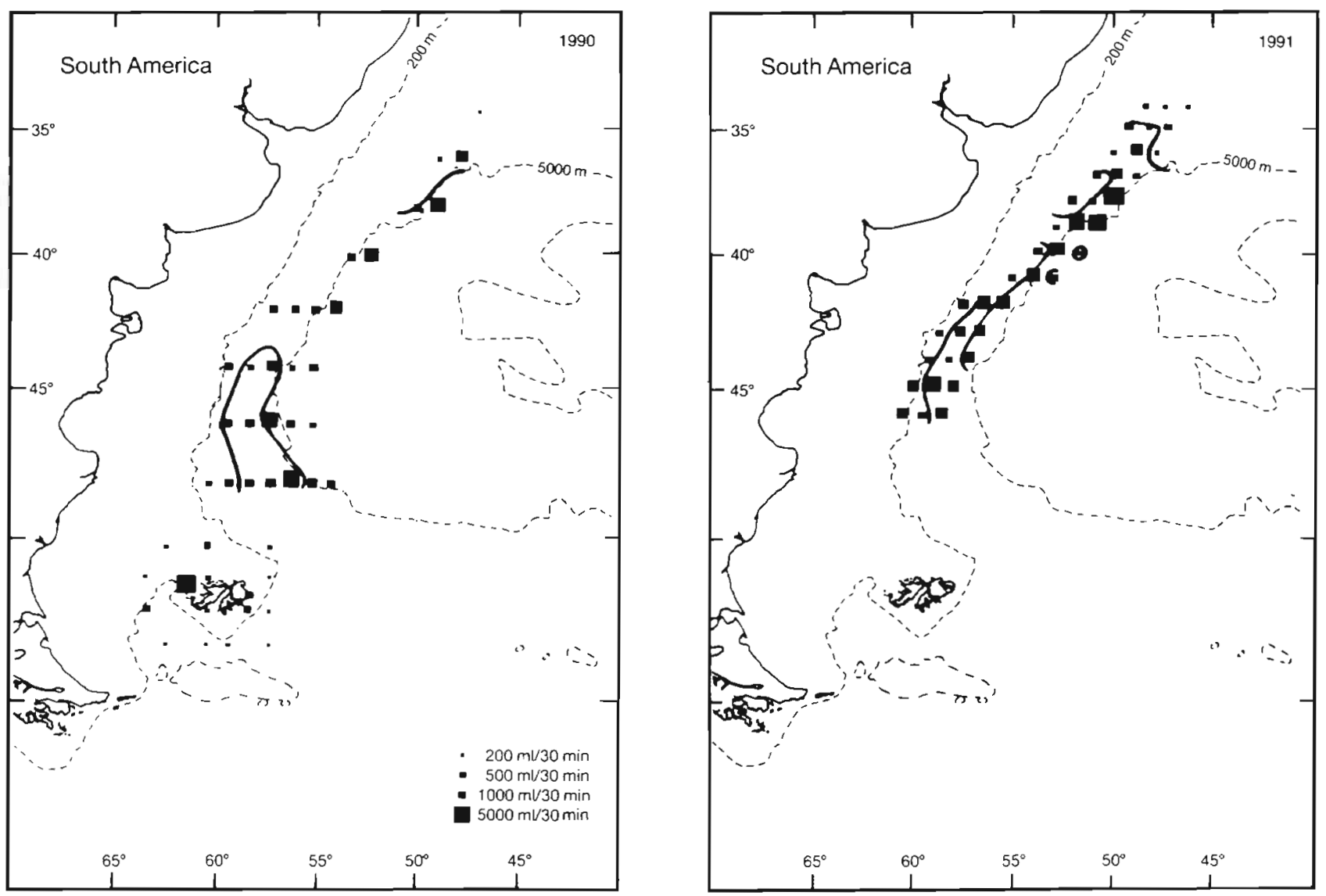

Fig. 7. Bongo net settled zooplankton volumes and the major oceanographic features: 1990 and 1991 (box area proportional to zooplankton volume) 
Table 3. Cephalopod distribution in relation to the Subtropical Zone (STZ), the Subantarctic Zone (SAZ) and the Polar Frontal Zone (PFZ) in 1990

\begin{tabular}{|c|c|c|c|}
\hline Location (net types, tow depth) & STZ & SAZ & PFZ \\
\hline \multicolumn{4}{|c|}{ Patagonian shelf/off shelf (RMT8;0-300 m) } \\
\hline Taningia danae & 1 & & \\
\hline Histioteuthis corona corona & 1 & & \\
\hline Histioteuthis atlantica & 1 & 4 & \\
\hline Abraliopsis pfefferi & 3 & 1 & \\
\hline Brachioteuthis sp. & 1 & 2 & \\
\hline Chiroteuthis sp. & 1 & 1 & \\
\hline Galiteuthis sp. & 1 & 4 & 3 \\
\hline Unidentified cranchiids & 2 & 8 & 9 \\
\hline Unidentified teuthoids & 3 & 12 & 14 \\
\hline Gonatus antarcticus & & 1 & \\
\hline Teuthowenia sp. & & 1 & \\
\hline Batoteuthis skolops & & 1 & \\
\hline Histioteuthis eltaninae & & 2 & \\
\hline Histioteuthis macrohista & & 2 & \\
\hline Histioteuthis $\mathrm{sp}$ & & 1 & \\
\hline Haliphron atlanticus & & 1 & \\
\hline \multicolumn{4}{|c|}{ Patagonian shelf/off shelf (Bongo; surface only) } \\
\hline Unidentified ommastrephids & 2 & & \\
\hline Unidentified teuthoids & 6 & 24 & 12 \\
\hline Gonatus antarcticus & & 30 & 127 \\
\hline \multicolumn{4}{|c|}{ Falkland shelf (RMT8; surface to bottom) } \\
\hline Martialia hyadesi & 1 & & \\
\hline Moroteuthis knipovitchi & 1 & & \\
\hline Semirossia patagonica & 2 & & \\
\hline Octopus sp. & 27 & & \\
\hline Unidentified teuthoids & 2 & & \\
\hline
\end{tabular}

around the STF), the typically subantarctic Batoteuthis skolops, $H$. eltaninae and $H$. macrohista and the typically subantarctic/antarctic Gonatus antarcticus. H. atlantica, $H$. macrohista and $G$. antarcticus were caught at, or near, the $5000 \mathrm{~m}$ stations in the eastern region of the SAF, while $H$. eltaninae was caught on the southwestern section of the SAF.

The PFZ was relatively poor in species. Apart from a single specimen of Histioteuthis eltaninae and some unidentified cranchiids, the only species caught in any number were small specimens of the subantarctic/ antarctic Gonatus antarcticus. In 1990 a total of 29 G. antarcticus were caught on the southwestern boundary of the SAF with the remainder (ca 100) caught in the centre of the most southerly transect. Although still in the PFZ, this central station had a pronounced temperature minimum and was thus closer to the PF than any other station. Less species were caught in the PFZ during the 1991 survey.

Paralarval distribution around the Falkland Islands is shown in Figs. 8, $910 \& 11$. All the paralarvae were caught on the continental shelf, inshore of the $200 \mathrm{~m}$ isobath. Loligo gahi paralarvae were caught in greatest concentrations at the inshore stations around East
Table 4. Cephalopod distribution in relation to the Subtropical Zone (STZ), the Subantarctic Zone (SAZ) and the Polar Frontal Zone (PFZ) in 1991

\begin{tabular}{|c|c|c|c|}
\hline Location (net types, tow depth) & STZ & SAZ & PFZ \\
\hline \multicolumn{4}{|c|}{ Patagonian shelf/off shelf (Bongo; surface-50 m) } \\
\hline Rhynchoteuthion type B & 7 & & \\
\hline Rhynchoteuthion type C & 1 & & \\
\hline Unidentified teuthoids ${ }^{a}$ & $6^{b}$ & 5 & \\
\hline Unidentified teuthoids & $10^{c}$ & 8 & $10^{\mathrm{d}}$ \\
\hline Brachioteuthis sp. & & 2 & \\
\hline Unidentified ommastrephid & & 2 & \\
\hline Histioteuthis eltaninae & & 1 & 1 \\
\hline Gonatus antarcticus & & 4 & 8 \\
\hline \multicolumn{4}{|c|}{ Falkland shelf (RMT8; surface to bottom) } \\
\hline Batoteuthis skolops & 1 & & \\
\hline Moroteuthis knipovitchi & 2 & & \\
\hline Unidentified cranchiids & 3 & & \\
\hline Martialia hyadesi & 6 & & \\
\hline Unidentified teuthoids & 10 & & \\
\hline Semirossia patagonica & 134 & & \\
\hline Loligo gahi & 141 & & \\
\hline Gonatus antarcticus & 249 & & \\
\hline Octopus sp. & 1273 & & \\
\hline \multicolumn{4}{|c|}{$\begin{array}{l}\text { "Three blue photophores on ventral surface of eye } \\
\text { "All in the large warm core eddy } \\
\text { "Five in the large warm core eddy, one in the small warm } \\
\text { core eddy }\end{array}$} \\
\hline
\end{tabular}

Falkland and were only caught when the RMT8 was fished close to the seabed in shallow water $<100 \mathrm{~m}$ in depth (i.e. in 1991). Martialia hyadesi and Moroteuthis knipovitchi were also caught relatively close to the coast of East Falkland, with Martialia hyadesi to the north and east of the island and Moroteuthis knipovitchi along the north coast only. In contrast, Gonatus antarcticus was considerably more widespread and occurred in greatest concentrations at the offshore stations, particularly to the south of East Falkland. Octopus sp. was the most widely distributed of the cephalopods, occurring in the large coastal bays of both East and West Falkland. The distribution and numbers of Octopus sp. obtained suggest there may be large stocks in the region. A single specimen of Batoteuthis skolops was caught to the south of the main islands near the shelf break and Semirossia patagonica was caught around East and West Falkland with the 2 largest catches occurring to the north of the sound between the 2 islands.

\section{DISCUSSION}

The results show a marked association between species distribution and large scale oceanographic 


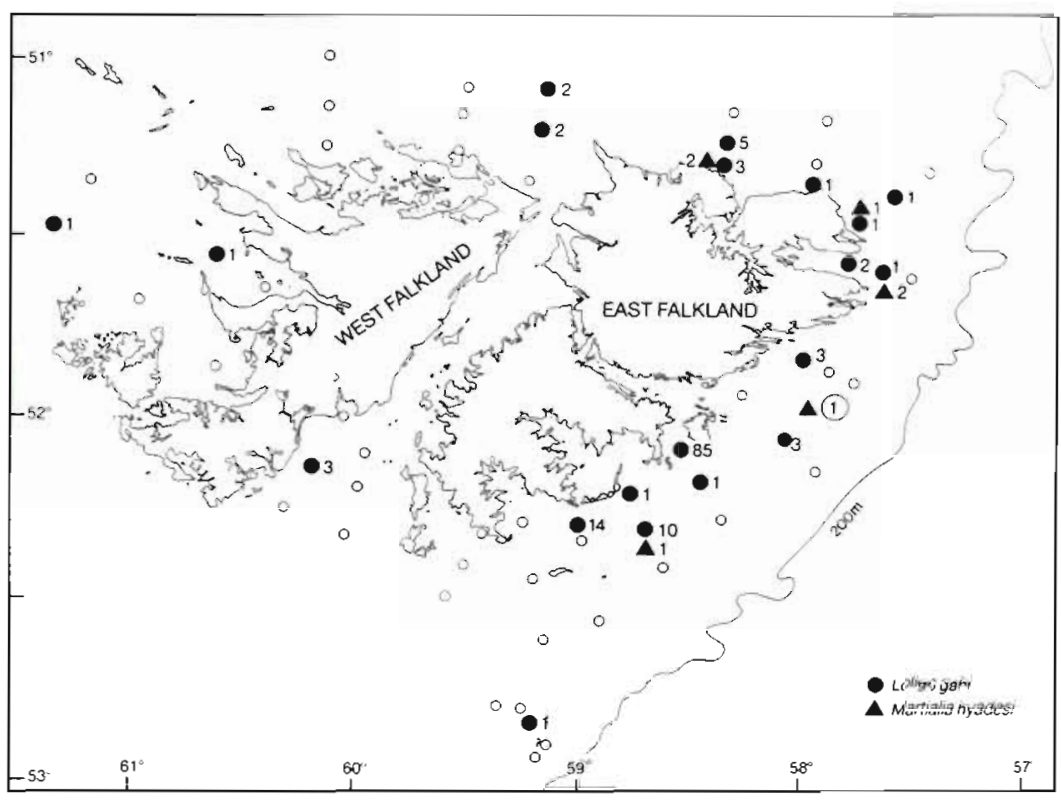

Fig. 8. Loligo gahi, Martialia hyadesi. Location and no. of ind found on the Falkland Island shelf. Circled values are from 1990, uncircled values from 1991

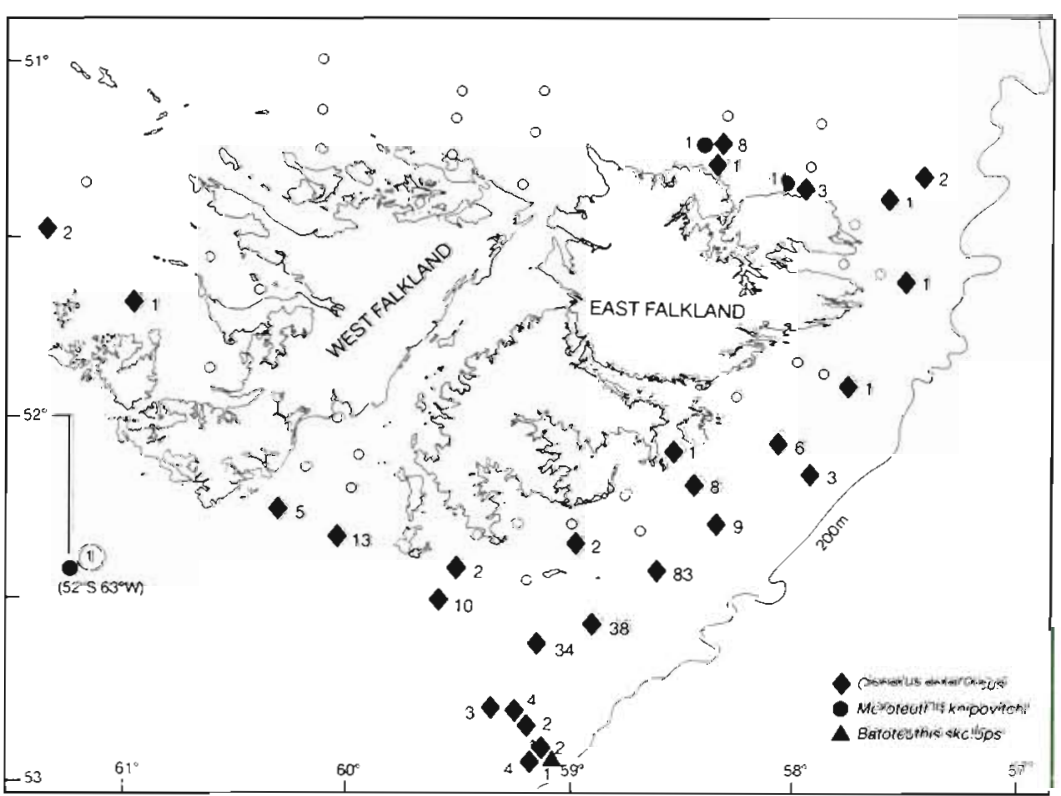

Fig. 9. As in Fig. 8 but for Gonatus antarcticus, Moroteuthis knipovitchi and Batoteuthis skolops

features (i.e. the STZ, SAZ and PFZ) and the mesoscale eddies and fronts. It is possible that several species are associated with different aspects of the large-scale system at different life stages, as proposed for lllex argentinus by Hatanaka et al. (1985). It is particularly important to identify these associations in the southwest Atlantic Ocean for the commercially important
I. argentinus, Martialia hyadesi and Loligo gahi and the ecologically important Gonatus antarcticus.

The presence of ommastrephid rhynchoteuthion paralarval types $\mathrm{B}$ and $\mathrm{C}$ and post-rhynchoteuthion paralarvae in the South Atlantic Central Water of the Brazil Current indicates that at least 2 ommastrephid species, including Illex argentinus, spawn in this water. This agrees with Brunetti \& Ivanovic's (1992) observations on the distribution of the rhynchoteuthion stage and with Hatanaka et al.'s (1985) hypothesis that spawning takes place in the Brazil Current. Their presence is not inconsistent with Brunetti \& Ivanovic's (1992) proposal that spawning may occur in the Falkland Current with the eggs carried northwards to the Brazil Current. The general paucity of ommastrephid paralarvae in the northern phases of the 1990 and 1991 surveys suggests the distribution of young $I$. argentinus probably lies outside this area - although the present surveys did occur some 3 to 4 mo after the estimated peak spawning time for the commercially exploited population around the Falkland Islands (Rodhouse \& Hatfield 1990). Thus, future surveys for $I$. argentinus paralarvae should include the period immediately following the estimated peak spawning time and should concentrate on the interface of the Patagonian shelf/slope water with the western boundaries of the Brazil and Falkland Currents. As the paralarvae of the north Atlantic I. illecebrosus concentrate at the interface between the slope water of the north American continental shelf and the Gulf Stream (Vecchione 1979, Dawe \& Beck 1985, Rowell \& Trites 1985, Vecchione \& Roper 1986) the corresponding region of the Patagonian shelf/slope would appear to be the most likely habitat for I. argentinus paralarvae.

The presence of Martialia hyadesi juveniles (ML $<34 \mathrm{~mm}$ ) on the shelf to the east of the Falkland Islands shows that at least part of the southwest Atlantic Ocean population spawns in the vicinity of the interface between the Patagonian shelf/slope water and the western boundary of the Falkland Current, and the presence of young juveniles in October/November indicates that at 
least some spawning occurs in the late austral winter or spring. This is the first record of juvenile specimens of $M$. hyadesi in the Atlantic sector of the Southern Ocean. Juveniles have been recorded in the Pacific sector of the Southern Ocean (Uozomi et al. 1991) in, and to the south of, the STF to the southeast of New Zealand. As that study found the highest abundance of juveniles on the Auckland Island shelf it was concluded that spawning must have occurred in that vicinity. In combination with the results of this study, it seems $M$. hyadesi may spawn in SAZ water reasonably close to a shelf break.

Catches of Loligo gahi paralarvae were concentrated around East Falkland, inshore of the areas which broadly correspond to the major fishing grounds (Patterson 1988). This supports the conclusions of Hatfield et al. (1990) who suggest that L. gahi migrate inshore to spawn and then migrate into deeper water during ontogenesis. The South African L. vulgaris reynaudii spawns at depths of 18 to $28 \mathrm{~m}$ in areas of low relief reef interspersed with coarse sand in gently shelving protected bays (Augustyn 1990). Large catches of L. gahi paralarvae off East Falkland suggests this species may select a similar habitat for spawning. The size-frequency data show a bimodal distribution (Hatfield 1992), consistent with one of the major seasonal broods having a hatching peak in August (Hatfield 1991) and another having a hatching peak in June. These represent 2 of the 3 broods which appear to recruit annually into the commercial fishery (Hatfield 1992). All L. gahi paralarvae were taken in November 1991.

Gonatus antarcticus paralarvae appear to be associated with the PFZ and SAZ water of the Falkland Current, moving in over the shelf to the east of East Falkland. As this species must spawn in the vicinity of the Falkland Islands, it is likely that a proportion of the hatching paralarvae are retained in the area with the remainder carried offshore in the main flow of the Falkland Current. The presence of young paralarvae in October/November indicates that at least part of the population spawns in the late austral winter or spring. Juveniles (ML 29 to $36 \mathrm{~mm}$ )

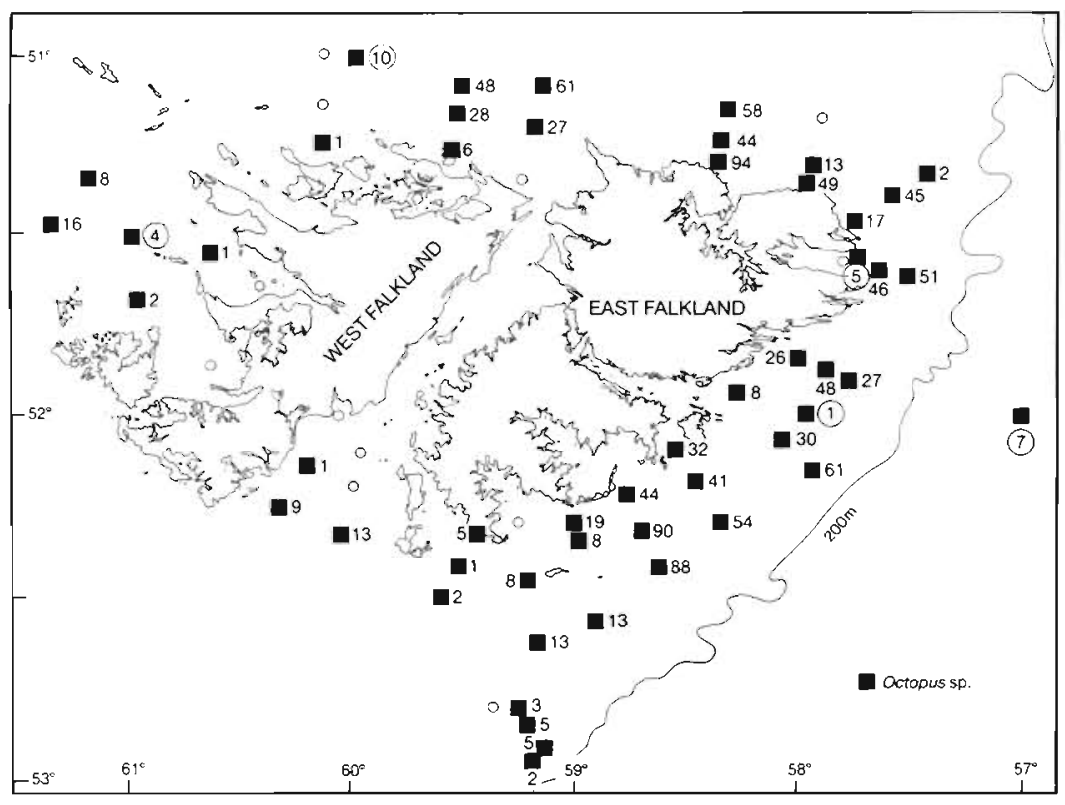

Fig. 10. As in Fig. 8 but for Octopus sp.

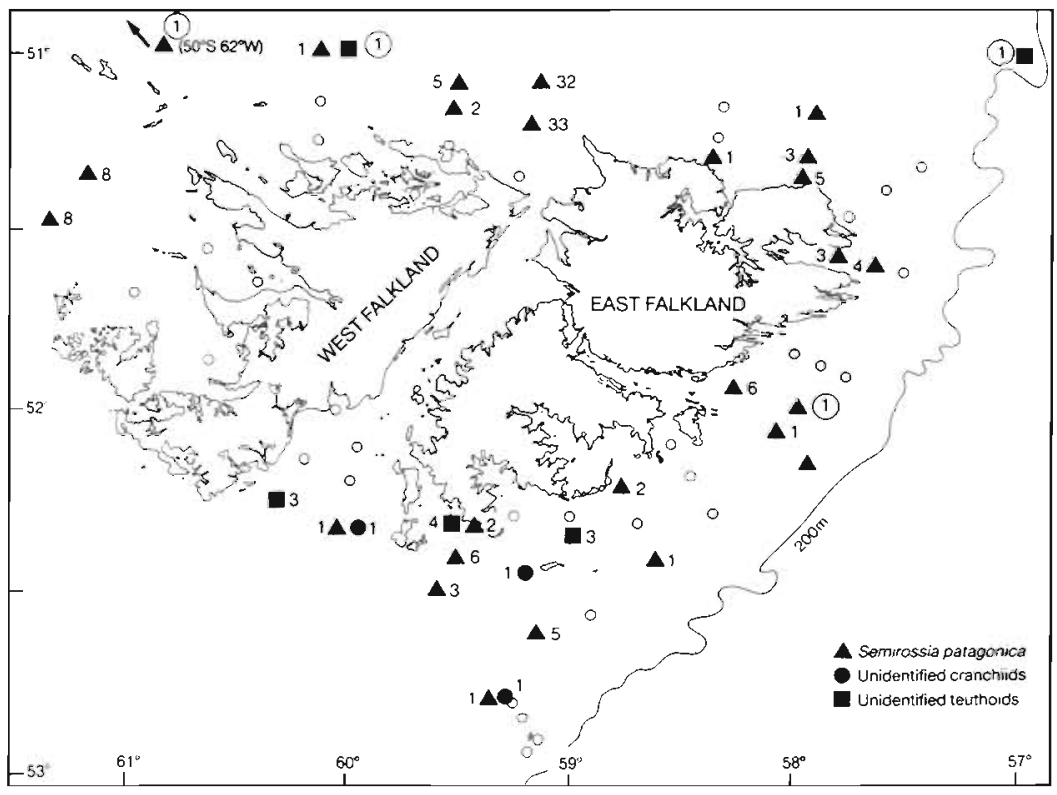

Fig. 11. As in Fig. 8 but for Semirossia patagonica, unidentified cranchiids and other unidentified teuthoids

are frequently selected by seabirds breeding on the Falkland Islands, particularly magellanic, rockhopper and gentoo penguins for which at least $30 \%$ of the diet may be squid [with $G$. antarcticus comprising up to $50 \%$ of the squid component ( $\mathrm{K}$. Thompson pers. comm.)]. Our observations together with the reported seabird predation (Thompson 1989) suggests the shelf/slope waters around the Falkland Islands as a possible nursery ground. 


\section{CONCLUSION}

The Falkland Current/Brazil Current system has strongly flowing northerly and southerly components, marked gradients in temperature, salinity and current velocity and relatively fixed boundaries (between the currents and the shelf/slope water and, to a lesser extent, between the currents themselves). It is likely that cephalopod life cycles have evolved to exploit these variations, with larval phases concentrating on the Patagonian shelf/off shelf area and the adult phases exploiting the currents for migrations between the spawning and feeding grounds. Interannual variability in the physical system could thus have profound effects on the year class strength of species whose life cycles are adapted to exploit these features. As the relationships between cephalopod life cycles and the mesoscale/largescale oceanographic regime become more clear, observed variability in the stocks of commercially and ecologically important cephalopods will be easier to resolve. Although this study has shown a marked association between the physical environment and particular life stages of particular species of cephalopod, further work is required to establish the variation in these associations for the different life stages (i.e. from eggs to spawning adults). Such information will ultimately lead to a greater understanding of the cephalopod ecology of the southwest Atlantic Ocean and, for the commercially important species, more sustainable management of stocks.

Acknowledgements. We thank Douglas Bone for his considerable efforts in preparing the sampling gear for seagoing research at the start of this programme and for testing the gear aboard the MV 'Falklands Protector'. We also thank the following for their assistance at sea and ashore in the Falkland Islands: the Captain, officers and crew of the MV 'Falklands Protector', John Barton, Conor Nolan, Elizabeth Marrow, Martin Collins, Jo Hunter, Joost Pompert, and Geraint Tarling. Tony Sylvester and Roger Missing were responsible for the artwork and Sophie Gajdatsy was responsible for sorting and measuring cephalopod material in Cambridge. Richard Young, Nancy Voss and Denise Reichow advised on the identification of cephalopod paralarvae and small juveniles. Research at the British Antarctic Survey on commercially exploited cephalopods in the southwest Atlantic Ocean is funded by the Falkland Islands Government.

\section{LITERATURE CITED}

Augustyn, C. J. (1990). Biological studies on the chokker squid Loligo vulgaris reynaudii (Cephalopoda: Myopsida) on spawning grounds off the south east coast of South Africa. S. Afr. J. mar. Sci. 9:11-26

Brakoniecki, T F. (1984). A full description of Loligo sanpaulensis, Brakoniecki, 1984 and a redescription of Loligo gahi d'Orbigny, 1835, two species of squid
(Cephalopoda: Myopsida) from the southwest Atlantic. Bull. mar. Sci. 34: 435-448

Brunetti, N. E. (1990). Description of rhynchoteuthion larvae of Illex argentinus from the summer spawning population. J. Plankton Res. 12: 1045-1057

Brunetti, N. E., Ivanovic, M. L. (1992). Distribution and abundance of early life stages of squid (Illex argentinus) in the south-west Atlantic. ICES J. mar. Sci. 49: 175-183

Clarke, M. R. (1969). A new midwater trawl for sampling discrete depth horizons. J. mar. biol. Ass. U.K. 49: 945-960

Clarke, M. R. (1980). Cephalopods in the diet of sperm whales of the southern hemisphere and their bearing on sperm whale biology. Discovery Rep. 37: 1-324

Csirke, J (1987). The Patagonian fishery resources and the offshore fisheries in the South-West Atlantic. FAO Fish. tech. Pap. 286

Dawe, E. G., Beck, P. C. (1985). Distribution and size of juvenile short-finned squid (Illex illecebrosus) (Mollusca: Cephalopoda) south of Newfoundland during the winter. Vie Milieu 35: 139-147

Garzoli, S. L., Biabchi, A. (1987). Time-space variability of the local dynamics of the Malvinas-Brazil Confluence as revealed by inverted echo sounders. J. geophys. Res. 92: 1914-1922

Gordon, A. L., Greengrove, C. L. (1986). Geostrophic circulation of the Brazil-Falkland Confluence. Deep Sea Res. 33: 573-585

Harman, R. F., Young, R. E. (1985). The larvae of ommastrephid squids (Cephalopoda: Teuthoidea) from Hawaiian waters. Vie Milieu 35: 211-222

Hatanaka, H., Kawahara, S., Uozumi, Y., Kasahara, S. (1985). Comparison of life cycles of five ommastrephid squids fished by Japan: Todarodes pacificus, Illex illecebrosus, Illex argentinus, Nototodarus sloanii and Nototodarus gouldi. NAFO Sci. Coun. Studies 9: 59-68

Hatfield, E. M. C. (1991). Post recruit growth of the Patagonian squid Loligo gahi (d'Orbigny). Bull. mar. Sci. 49: $349-361$

Hatfield, E. M. C. (1992). Recruitment, demography and growth of the Patagonian squid Loligo gahi (d'Orbigny, 1835) in Falkland Island waters. Ph.D. thesis, Council for National Academic Awards (C.N.A.A.), London

Hatfield, E. M. C., Rodhouse, P. G., Porebski, J. (1990). Demography and distribution of the Patagonian squid Loligo gahi d'Orbigny, 1835 during the austral winter. J. Cons. int. Explor. Mer 46: 306-312

Kubodera, T., Okutani, T. (1986). New and rare cephalopods from the Antarctic waters. Mem. Natl Inst. Polar Res. Spec Issue 44: 129-143

Legeckis, R., Gordon, A. L. (1982). Satellite observations of the Brazil and Falkland currents - 1975 to 1976 and 1978 Deep Sea Res. 29: 375-401

Olson, D. B., Podesta, G. P., Evans, R. H., Brown, O. B. (1988). Temporal variations in the separation of the Brazil and Malvinas currents. Deep Sea Res. 35: 1971-1990

Nesis, K. N. (1987). Cephalopods of the world. T F. H. Publications, Neptune City, NJ

Patterson, K. R. (1988). Life history of Patagonian squid Loligo gahi and growth parameter estimates using least squares fits to linear and von Bertalanffy models. Mar. Ecol. Prog. Ser. 47: 65-74

Peterson, R. G., Whitworth ill, T. (1989). The Subantarctic and Polar Fronts in relation to deep water masses through the southwestern Atlantic. J. geophys. Res. 94: 10817-10838

Roden, G. I. (1986). Thermohaline fronts and baroclinic flow in the Argentine Basin during the austral spring of 1984. J. geophys. Res. 91: 5075-5093 
Rodhouse, P. G. (1990) Cephalopod fauna of the Scotia Sea at South Georgia: potential for commercial exploitation and possible consequences. In: Kerry, K., Hempel, G. (eds.) Ecological change and the conservation of Antarctic ecosystems. Proc 5th SCAR Symp. Antarct. Biol. SpringerVerlag, Berlun, p. 289-298

Rodhouse, P. G., Arnbom, $\urcorner$ R., Fedak, M. A., Yeatman, J., Murray, A. W. A. (1992). Cephalopod prey of the southern elephant seal Mirounga leonina L. Can. J. Zool. 70: $1007-1015$

Rodhouse, P. G., Clarke, M. R., Murray, A. W. A. (1987). Cephalopod prey of the Wandering Albatross Diomedea exulans. Mar. Bio]. 96: 1-10

Rodhouse, P. G., Hatfield, E. M. C. (1990). Dynamics of growth and maturation in the cephalopod Illex argentinus de Castellanos, 1960 (Teuthoidea: Ommastrephidae. Phil. Trans. R. Soc. Lond. Ser. B. 329: 229-241

Rodhouse, P. G., Prince, P. A., Clarke, M. R., Murray, A. W. A (1990). Cephalopod prey of the grey-headed albatross Diomedea chrysostoma. Mar. Biol. 104: 353-362

Rodhouse, P. G., Yeatman, J (1990). Redescription of Martialia hyadesi Rochbrune and Mabille, 1889 (Mollusca: Cephalopodal from the Southern Ocean. Bull. Br. Mus. nat. Hist. (D: Zool) 56: 135-143

Roper, C. F. E. (1983). An overview of cephalopod systematics: status, problems and recommendations. Mem. nat. Mus. Victoria, Melbourne 44: 13-27

Roper, C. F. E., Lu, C. C. (1979). Rhynchoteuthion larvae of ommastrephid scuids of the western north Atlantic, with the first description of larvae and juveniles of Illex illecebrosus. Proc. Biol. Soc. Wash. 91: 1039-1059

Roper, C. F. E., Young, R. E., Voss, G. L. (1969). An illustrated key of the families of the order Teuthoidea (Cephalopoda). Smithsonian Contributions to Zoology 13, Washington, D.C.

Rowell, T. W., Trites, R. W. (1985). Distribution of larval and juvenile Illex (Mollusca: Cephalopoda) in the Blake Plateau

This article was subnritted to the editor region (northwest Atlantic). Vie Milieu: 35: 149-161

Steedman, H. F. (1976). General and applied data on formaledehyde fixation and preservation of marine organisms. In: Steedman, H. F. (ed.) Zooplankton fixation and preservation. UNESCO, Paris, p. 103-154

Stramma, L., Peterson, R. G. (1990). The South Atlantic Current. J. phys. Oceanogr. 20: 846-859

Sweeney, M. J., Roper, C. F. E., Mangold, K. M., Clarke, M. R., Boletzky, S.v., (1992). 'Larval' and juvenile cephalopods: a manual for their identification. Smithsonian Contributions to Zoology 513, Washington, D.C.

Thompson, K. R. (1989). An assessment of the potential for competition between seabirds and fisheries in the Falkland Islands. Falkland Islands Foundation, Brighton

Uozomi, Y., Forch, E. C., Okazaka, T. (1991). Description and morphological characters of immature Martialia hyadesi (Cephalopoda: Oegopsida) in New Zealand waters. N.Z. J. mar. freshw. Res. 25: 275-282

Vecchione, M. (1979). Larval development of Illex Steenstrup, 1880 , in the northwestern Atlantic, with comments on Illex larval distribution. Proc. Biol. Soc. Wash. 91: 1060-1075

Vecchione, M. (1987). Juvenile ecology. In: Boyle, P. R. (ed.) Cephalopod life cycles, Vol. II. Academic Press, London, p. 61-84

Vecchione, M., Roper, C. F. E. (1986). Occurrence of larval thex Hecebrosus and other young cephalopods in the slope water/ Gulf Stream interface. Proc. Biol. Soc. Wash. 99: 703-708

Voss, N. A. (1969). A monograph of the cephalopoda of the north Atlantic. The family Histioteuthidae. Bull. mar. Sci. 19: 713-867

Young, R. E., Hirota, J. (1990). Description of Ommastrephes bartramii (Cephalopoda: Ommastrephidae) paralarvae with evidence for spawning in Hawaiian waters. Pacif. Sci. 44: $71-80$

Young, R. E., Roper, C. F. E. (1968). The Batoteuthidae, a new family of squid (Cephalopoda; Oegopsida) from Antarctic waters. Antarct. Res. Ser 11: 185-202

Manuscript first received: August 17, 1992

Revised version accepted: October 28, 1992 